\author{
Humanities and Social Sciences Letters \\ 2022 Vol. 10, No. 1, pp. 11-26. \\ $\operatorname{ISSN}(e): 2312-4318$ \\ $\operatorname{ISSN}(p): 2312-5659$ \\ DOI: $10.18488 / 73 . v 10 i 1.2227$ \\ (C) 2022 Conscientia Beam. All Rights Reserved. \\ check for
updates
}

\title{
DOES CORPORATE GOVERNANCE AND OTHER FACTORS INFLUENCE EARNINGS MANAGEMENT? A STUDY ON INDONESIA'S BANKING SECTOR
}

\author{
Sigit Handoyo ${ }^{1+}$ \\ Inneke Tri \\ Kusumaningrum ${ }^{2}$
}

\author{
${ }^{1,2}$ Faculty of Business and Economics, Universitas Islam Indonesia, Indonesia. \\ 'Email: sigit.handoyo@uii.ac.id Tel: +628170423426 \\ Email: olkeinneke48@gmail.com Tel: +6281915527931
}

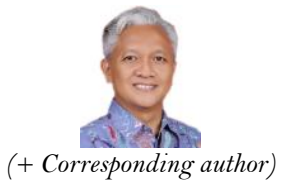

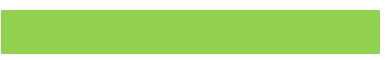

Article History

Received: 10 August 2021 Revised: 24 November 2021 Accepted: 16 December 2021 Published: 4 January 2022

\section{Keywords}

Earning management Mechanism of corporate governance

Dividend policy

Independent board of

commissioners

Independent audit committee

Managerial ownership

Indonesia's banking sector.

JEL Classification: G32.

\section{ABSTRACT}

The issue of misreporting financial data and earnings management has become more prominent in recent years. Several studies have been conducted determining the influences of the mechanisms of corporate governance and earnings management in various countries. In this study, it was proven that the existence of a good corporate governance (GCG) mechanism did not suppress earnings management practices in the banking sector industry in Indonesia. However, another factor, dividend policy, can prove effective in suppressing earnings management. The measurement of earnings management in this study was carried out using the Modified Jones model with a population of 43 conventional banks from which research data were taken using a purposive sampling technique sourced from the Indonesia Stock Exchange (IDX). The analysis was carried out using multiple linear regression. The implication of this research is that the implementation of good corporate governance by an entity must be considered given that earnings management practices in Indonesia are still relatively high.

Contribution/Originality: This paper's primary contribution is finding that even though the design of corporate governance is perfectly set, it cannot guarantee that earnings management practices will not occur. Earnings management practices are more due to the willingness of management to do so under the pretext of protecting the company.

\section{INTRODUCTION}

Financial statements issued by a company are prepared on an accrual basis because this method can better describe financial conditions in real terms. On the other hand, the use of the accrual basis in the recording of a company's financial statements by managers means there is also the freedom to choose the best accounting policies/methods to achieve the desired goal, either to increase profits or reduce company losses, which is a benchmark for company performance. This is what is known as earnings management practice (Scott, 2009).

Jensen \& Meckling (1976) stated that earnings management activities are the other side of agency theory, which emphasizes the importance of handing over company operations from principals to agents who have the ability to manage the company better. This managerial concept regulates the relationship between owner and manager, which explains that each party has rights and responsibilities in managing a company. This means that each party must also have a commitment to respect the rights and authorities of other parties. 
The agency relationship between the owner and manager of the company should produce a mutually beneficial relationship for all parties, especially if all parties carry out their obligations responsibly. However, what happen ed was the opposite, namely the emergence of agency problems between the owners and managers of the company. This agency problem occurs as a result of differences in interests between company owners and their management team (Jensen \& Meckling, 1976).

In corporate governance, the existence of the board of commissioners is very important because it can alleviate problems that can ignore the interests of public shareholders (minority shareholders) and other stakeholders (Mahadewi \& Krisnadewi, 2017). In realizing good corporate governance in the banking environment, Bank Indonesia itself issued Bank Indonesia Regulation Number 8/4/PBI/2006 concerning the Implementation of Good Corporate Governance for Commercial Banks. Based on this regulation, at least $50 \%$ of the total members of the board of commissioners are independent commissioners. Thus, the existence of an independent board of commissioners is a must for every company. The greater the number of independent commissioners, the more stringent and comprehensive the supervision of financial statements is expected to be, so that fraud committed by managers to manipulate earnings can be minimized or avoided. This is evidenced by research conducted by Chtourou, Bédard, \& Courteu (2001) and Xie, Davidson III, \& DaDalt (2003), which proves that an independent board of commissioners has a negative effect on earnings management.

Share ownership encourages managers to have interests that are aligned with those of the investors (Santana \& Made, 2016). Theoretically, management with a high percentage of share ownership in the company will act like someone who holds an interest in the company. This assumption is in line with the contracting-based theory, which shows that management will be more efficient in determining accounting methods that will provide added value for the company (Christie \& Zimmerman, 1994), and so that the risk of earnings management practices carried out by managers can be minimized. Several previous studies examining managerial ownership in earnings management were conducted by Ujiyantho \& Scouts (2007) and Teshima \& Okinobu (2008); Alves (2012) argues that managerial ownership has a negative effect on earnings management.

The audit committee has a role to ensure the credibility of financial reporting and reduce the possibility of management committing fraud (Harrast \& Mason-Olsen, 2007). Based on the JSE Circular, SE-008/12-2001, the audit committee consists of at least three members including the chairman of the audit committee. There is only one member of the audit committee from the board of commissioners who is an independent commissioner and also serves as chairman of the committee. Other members who are not independent commissioners must come from independent external parties (Suriyani, Yuniarta, \& Atmadja, 2015).

In addition to the implementation of good corporate governance, earnings management activities can also be influenced by dividend policy. Earnings management carried out by the management is inseparable from the differences in interests between the management (agent) and the owner (principal). The principal has a role in determining the company's dividend policy. The size of the dividend payout ratio can be influenced by the decision of the General Meeting of Shareholders made by the company, and the decision to produce the size of the company's dividend payout ratio cannot necessarily be determined by the management (Sulistiyawati, 2013). The research conducted by $\mathrm{He}, \mathrm{Ng}$, Zaiats, \& Zhang (2017) proved that if there is a dividend policy, the practice of earnings management will be further suppressed. Meanwhile, research conducted by Haider (2012) in Pakistan proved that dividend policy is not related to earnings management practices.

In the period from 2015 to 2017 , there were several problems with financial statements issued by public companies in the banking sector in Indonesia. For example, one bank in Indonesia engineered financial statements in 2015, 2016, and 2017. The steps taken by the bank have attracted the attention of the relevant authorities, namely the Indonesia Stock Exchange (IDX) and the Financial Services Authority (OJK). According to information compiled by Consumer News and Business Channel (CNBC), modifications to the credit card data at the bank had been carried out more than five years earlier. The number of modified credit cards is also quite large, at more than 
100,000. The modifications caused the credit position and income of the Bank to increase improperly. The bank revised its 2016 net profit to $\mathrm{Rp} 183.56$ billion from the previous $\mathrm{Rp} 1.08$ trillion. The biggest decline was in the income of fees and commissions, which was income from credit cards. This income decreased from Rp 1.06 trillion to Rp 317.88 billion, which finally put the bank in big trouble and faced bankruptcy in 2020.

One of the things that can be done to avoid earnings management practices is the implementation of good corporate governance. The implementation of good corporate governance is expected to be an obstacle which will reduce agents' fraudulent behavior, so that the company's financial statements will contain accurate information. Several corporate governance mechanisms can be realized, among others, by the existence of an independent board of commissioners, independent audit committee, and share ownership structure in a company, although users of financial statements are greatly influenced by the character of investors. There are two characters of investors, namely rational and irrational. Rational investors will prioritize mathematical calculations, while irrational investors will prioritize emotional attitudes and behavior by ignoring economic laws because they are driven by biased psychological attitudes (Hodnett \& Hsieh, 2012). The reason why this research was conducted using data from 2015 to 2017 on companies in the banking sector in Indonesia is because in that period there was a high occurrence of earnings management, so this study is based on accurate data that can answer how the existence of a corporate governance mechanism can reduce earnings management practices, and whether factors outside of the corporate governance mechanism, such as dividend policy, will be able to minimize earnings management practices or not.

\section{LITERATURE STUDY}

\subsection{Agency Theory and Earnings Management}

Agency theory is the basis used to understand corporate governance and earnings management, and it is related to the relationship or contract between members of the company, especially the relationship between owners (principals) and management (agents). Jensen \& Meckling (1976) define agency relationship as a contract between one or more people (principals) who hire others (agents) to perform services, including the delegation of decisionmaking authority to agents. The agency relationship between the owner and manager of the company should result in a mutually beneficial relationship for all parties, especially if each party carries out their obligations responsibly. However, in reality, the opposite is true, namely the emergence of agency problems between the owners and managers of the company. Agency problems occur due to differences in interests between company owners and their managers (Jensen \& Meckling, 1976). Eisenhardt (1989) states that agency theory uses three types of human assumptions - humans are generally self-interested, have limited thinking power about future perceptions (bounded rationality), and, in general, always avoid risk (risk averse). Based on the existence of human nature, a manager will tend to act in his own interest by practicing earnings management, and this triggers an agency conflict. Therefore, agency theory emphasizes more on determining efficient control in the relationship between the owner and the agent (Mahadewi \& Krisnadewi, 2017).

\subsection{Mechanism of Corporate Governance and Earnings Management}

There are several indicators in the corporate governance mechanism, including an independent board of commissioners, an independent audit committee, and managerial ownership. In relation to earnings management practices, the existence of the board of commissioners is considered capable of minimizing the occurrence of these practices. Therefore, this study focuses on the effect of independent board of commissioners, independent audit committee, and managerial ownership on earnings management. Existing studies on earnings management related to corporate governance mechanisms have produced inconsistent results. The results of research conducted by Chtourou et al. (2001); Xie et al. (2003); Rahmawati (2013); Mansor, Che-Ahmad, Ahmad-Zaluki, \& Osman (2013); Sufitrayati (2015); Nastiti, Gumanti, Utami, \& Manik (2015); Sinan, Hijazi, \& Al-Rahahleh (2016) and Mahadewi \& 
Krisnadewi (2017) showed that the independent board of commissioners has a negative and significant effect on earnings management. This is different from Syarifuddin (2013) and Dewi, Eva, \& Khoiruddin (2016), who showed that the independent board of commissioners has a positive effect on earnings management, while the research conducted by Murhadi (2010); Hermiyetti \& Manik (2013); Suriyani et al. (2015); Yendrawati (2015); Khosheghbal, Ali, \& Ali (2017) and Handoyo \& Agustianingrum (2017) showed that independent commissioners have no effect on earnings management.

Research on earnings management that used the independent audit committee as an independent variable was carried out by Murhadi (2010); Rahmawati (2013); Hermiyetti \& Manik (2013); Dewi et al. (2016) in Indonesia, and Khosheghbal et al. (2017) in Iran, and showed that the independent audit committee had no effect on earnings management. This is contrary to research conducted by Law (2011); Mansor et al. (2013); Sinan et al. (2016); Yendrawati (2015) and Handoyo \& Agustianingrum (2017), who found that the independent audit committee had a negative effect on earnings management. Meanwhile, according to the results of research by Sun, Lan, \& Liu (2014), the existence of an independent audit committee was found to have a positive effect on earnings management practices.

Another variable that was also investigated by previous researchers is the managerial ownership variable. The results of research conducted by Alves (2012); Syarifuddin (2013); Mansor et al. (2013); Sinan et al. (2016) and Handoyo \& Agustianingrum (2017) evidenced that managerial ownership had a significant negative effect on earnings management, while research conducted by Rahmawati (2013); Hermiyetti \& Manik (2013); Yendrawati (2015); Dewi et al. (2016) and Khosheghbal et al. (2017) in Iran proved that managerial ownership has no effect on earnings management. From some of the results of the research mentioned above, we can conclude that the results of these studies still show inconsistencies. This could also be due to the fact that, at the time of the research, the data were taken from banks that were in a stable condition. In contrast to this study, the data were taken from banks which, in the period from 2015 to 2017 , were experiencing problems that were closely related to earnings management practices.

\subsection{Dividend Policy and Earnings Management}

There are three arguments regarding dividend policy relating to companies that are still being debated. This happens because dividends are still regarded as confusing (dividend puzzle). The argument was put forward by Miller \& Modigliani (1961); Lintner (1962); Gordon (1960), and Litzenberger \& Ramaswamy (1982), who explained it with three theories. The first is the theory of Miller \& Modigliani (1961), which states that dividends are irrelevant, and that dividend payments have no effect on the welfare of shareholders. The second theory states that dividends can increase shareholder welfare. Gordon and Lintner's theory suggests that the higher the dividend payout ratio (DPR), the higher the firm value. Investors prefer to receive dividend payments at the present time rather than having to wait for capital gains from retained earnings. This Gordon-Lintner view by ModiglianiMiller was named the bird-in-the-hand fallacy, also known as the bird-in-hand theory. The third theory states that dividends reduce the level of shareholder welfare. Earnings management is carried out regardless of the differences in interests between the management and the principal (who has a role in determining the company's dividend policy). The size of the DPR can be influenced by the decision of the General Meeting of Shareholders (GMS). The decision to produce the size of the company's DPR cannot necessarily be detected by the management (Sulistiyawati, 2013). Research conducted by Handoyo \& Fathurrizki (2018) found that dividend policy had a positive and significant effect on income smoothing practices in Indonesia in the mining sector. However, research conducted by Haider (2012) in Pakistan proved that there was no relationship between dividend policy and earnings management. While the research conducted by He et al. (2017) of 29 countries proved that if there is a dividend policy, earnings management will decrease. 


\section{HYPOTHESIS DEVELOPMENT}

Earnings management practices can arise as a result of agency problems that occur due to a misalignment of interests between the owner (principal) and management (agent) or what is known as the agency problem. Company managers as agents are morally responsible for optimizing the profits of shareholders, but on the other hand, managers also have an interest in maximizing their own welfare. So there is a high possibility that agents do not always act in the best interests of company owners (Jensen \& Meckling, 1976). In general, the existence of an independent board of commissioners will greatly affect the operational performance of the company (Lin \& MinYen, 2014). This can be interpreted that the presence of independent commissioners who can increase supervisory actions will also have an impact on the lower use of discretionary accruals. Research conducted by Chtourou et al. (2001) and Xie et al. (2003) stated that the proportion of independent commissioners had a negative effect on earnings management.

Agency theory also explains that the owner delegates the authority and responsibility of managing the company to managers to work on behalf of and for the benefit of the owner. This delegation of authority causes managers to have incentives to make decisions that can benefit themselves so that agency problems arise between company owners and managers (Jensen \& Meckling, 1976). To avoid problems among interested parties, agency theory requires disclosure of financial statements.

Audit committee members play a role in assisting the board of commissioners to ensure that financial statements are presented fairly in accordance with generally accepted accounting principles, the company's internal control structure is well implemented, internal and external audits are carried out in accordance with applicable auditing standards, and follow-up audit findings implemented by management (Komite Nasional Kebijakan Governance (KKNG), 2006). Raja, Anugerah, Desmiyawati, \& Kamaliah (2014) and Handoyo \& Agustianingrum (2017) stated that an independent audit committee would ensure quality financial reporting, thereby minimizing the occurrence of earnings management. Managerial ownership is share ownership by the company's management. One way to reduce conflict between owners and managers can be done by offering managers an option to own company shares as managerial compensation. When associated with agency theory, share ownership by managers will encourage the pooling of interests between owners and managers of the company (Jensen \& Meckling, 1976). Managers who are given the authority to manage the company as well as stock options will not behave opportunistically because the company is also theirs. Managers will tend to be careful in making decisions, because the good or bad of every decision taken will have a direct impact on the welfare of the manager who is also the owner of the company's shares (Nastiti et al., 2015). Ujiyantho \& Scouts (2007); Handoyo \& Agustianingrum (2017) and O'Callaghan, Ashton, \& Hodgkinson (2018) proved that managerial ownership is able to become a corporate governance mechanism that can limit earnings management actions. This means that companies with a high level of managerial ownership are more likely to reduce earnings management practices. Investors in assessing the company really need information related to the company. One of them is information about dividend policy. Dividend policy is often considered as a signal for investors in assessing the good or bad of the company. This is because dividend policy can have an effect on the company's stock price. Dividend announcements are often considered to have information content if the market reacts when the announcement is received by the market. Dividend policy is a policy that is carried out with expenses that are not cheap, because a company must provide large amounts of funds that are used for dividend payment activities. Negative reactions often occur if the information in the dividend announcement invites pessimism about the prospects for future development of the company because the manager is considered unable to manage earnings for the long-term interests of shareholders. On the other hand, it will cause a positive reaction if the information in the dividend announcement causes a market response to the expectation of a higher level of profit in the future. Research conducted by He et al. (2017) and Putri (2012) showed that dividend policy has a significant and negative effect on earnings management. From the explanation above, the following hypotheses can be drawn: 
H1: The Independent Board of Commissioners has a negative effect on earnings management.

H2: The Independent Audit Committee has a negative effect on earnings management.

H3: Managerial Ownership has a negative effect on earnings management.

H4: Dividend policy has a negative effect on earnings management.

\section{RESEARCH METHODS}

The research method used is a method with a quantitative approach. The data used is secondary data in the form of data obtained from the annual report collected through the website www.idx.co.id. The technique used in determining the sample with certain considerations is the nonprobability sampling method with purposive sampling technique. The population in the study amounted to 43 companies. The sample companies that can be used are 18 companies. The research period is 3 years, so the total sample is 54 data banks.

\subsection{Research Variable}

\subsubsection{Dependent Variable}

The dependent variable in this study is earnings management which is measured by using discretionary accruals proxy. Discretionary accrual (DA) is an accrual component that allows managers to intervene in the preparation of financial statements, so that the earnings reported in the financial statements do not reflect the actual value or condition of the company. To calculate DA, the following four steps are taken:

1. Computation the value of total accrual (TAC) (1).

\section{TAC $=$ Nit - CFOit}

2. Computation of estimation of total accrual by calculating regression OLS (Ordinary Least Square) to determine $\beta 1, \beta 2$ and $\beta 3$

TACit/Ait-1 $=\beta 1(1 /$ Ait- 1$)+\beta 2(\Delta$ Salesit/Ait-1) $+\beta 3($ PPEit/Ait-1 $)+$ e $(2)$

3. By calculating $\beta 1, \beta 2$ and $\beta 3$, it can be calculated value of nondiscretionary accrual (NDTA) with formula :

$$
\text { NDAit }=\beta 1(1 / \text { Ait- })+\beta 2(\Delta \text { Salesit- } \Delta \text { Recit } / \text { Ait- } 1)+\beta 3(\text { PPEit } / \text { Ait- } 1)+\mathrm{e}(3)
$$

4. Last step is computation of discretionary accrual (DTA) using determined TACit/Ait-1 and NDAit in calculation before :

$$
\text { DAit }=\text { TACit/Ait-1 - NDAit }(4)
$$

$\begin{array}{ll}\text { Nit } & =\text { EBT at period } t \\ \text { CFOit } & =\text { Cash Flow at period } t \\ \text { TACt } & =\text { Total accrual at period } t \\ \text { Ait-1 } & =\text { Total Asset at period } t-1 \\ \Delta \text { Salesit } & =\text { Sales Difference at period } t \\ \text { PPEt } & =\text { Fixed Asset at period } t \\ \Delta \text { Recit } & =\text { Receivable fifference at period } t \\ \text { NDAit } & =\text { Total non-discretionary accrual at period } t \\ \text { DAit } & =\text { Total discretionary accrual at period } t \\ \beta 1, \beta 2, \beta 3 & =\text { Regression coefficient } \\ \mathrm{e} & =\text { Error }\end{array}$

\subsubsection{Independent Variable}

a. Independent Board of Commissioners

An independent board of commissioners is a member of the board of commissioners who has no financial, management, share ownership and/or family relationship with other members of the board of commissioners, directors and/or controlling shareholders or other relationships that may affect their ability to act independently 
(PBI No. 8 /4/ PBI/2006. Independent commissioners are measured based on the percentage of the number of independent commissioners to the total number of commissioners in the company's board of commissioners (Rahmawati, 2013). The data scale used is the ratio scale.

$$
\text { IBC }=\frac{\text { Number of Board of Commissioners from outside (independent) }}{\text { Number of Board of Commissioners }}
$$

\section{b. Independent Audit Committee}

The audit committee is a committee whose task is to assist the board of commissioners to ensure that the financial statements are presented fairly. Based on the IDX Circular, SE-008/BEJ/12-2001, the membership of the audit committee consists of at least three people, including the chairman of the audit committee. There is only one committee member who comes from the board of commissioners, this committee member is an independent commissioner as well as the chairman of the committee (Suriyani et al., 2015). To measure the independent audit committee variable, we observe the number or composition of the audit committee in banking companies that are used as research samples and calculate it as follows:

\section{IAC $=\frac{\text { Number of independent audit committee members }}{\text { Total Number of audit committee members }}$}

\section{c. Managerial Ownership}

Managerial ownership is the total share ownership by management of the total share capital of the company. Managerial ownership can also be the percentage of shares owned by directors and commissioners. The indicator used to measure managerial ownership is the percentage of the number of shares owned by the management of the entire company's outstanding share capital, as in the research conducted by Ujiyantho \& Scouts (2007); Iqbal \& Strong (2010) and Raja et al. (2014).

$$
\text { Managerial Ownership }=\quad \frac{\text { Number of shares owned by management }}{\text { Number of outstanding shares }}
$$

\section{d. Dividend Policy}

Dividend payment policy is a decision made in determining the amount of dividend paid by the company. In this study, dividend policy is measured using the dividend payout ratio (DPR). The DPR determined by the company to pay dividends to owners every year is based on the size of the earnings after tax.

$$
\text { Dividend payout ratio }=\frac{\text { Dividend per share }}{\text { Earnings per share }}
$$

\section{FINDINGS AND DISCUSSIONS}

Descriptive statistics are used to describe the data characteristics of each variable in this research. The analytical tools used are the average value, maximum value, minimum value, and standard deviation. Descriptive statistics describe data in a way that is clearer and easier to understand. Table 1 above presents descriptive information on the research variables, namely independent board of commissioners, independent audit committee, managerial ownership, dividend policy, and earnings management. Based on the results in Table 1, earnings management $(\mathrm{Y})$ that occurs in banking companies has an average of -8.1476 ; the negative result indicates that the average earnings management in banking companies is carried out by reducing corporate profits by -8.1476 units with a standard deviation of 2.0195. The highest earnings management (maximum) was found in Bank Mandiri (Persero) (4.2865), and the lowest (minimum) was found in Bank Nusantara Parahyangan Tbk (-5.9453). 
Table 1. Descriptive statistics.

\begin{tabular}{l|c|c|c|c|c}
\hline & $\mathbf{N}$ & Minimum & Maximum & Mean & Std. Deviation \\
\hline Earning Management & 54 & -5.9453 & 4.2865 & -8.1476 & 2.0195 \\
\hline Independent Board of Commissioners & 54 & 0.40 & 0.80 & 0.5548 & 0.08680 \\
\hline Independent Audit Committee & 54 & 0.33 & 0.80 & 0.6100 & 0.12035 \\
\hline Managerial Ownership & 54 & 0.01 & 0.63 & 0.0573 & 0.14650 \\
\hline Dividend Policy & 54 & 0.08 & 0.91 & 0.3749 & 0.19290 \\
\hline
\end{tabular}

The independent board of commissioners variable (X1) that occurs in banking companies has an average of 0.5548 with a standard deviation of 0.8680 . The highest number of independent board of commissioners was in the Regional Development Bank of West Java and Banten Tbk, and the Regional Development Bank of East Java Tbk (0.80) (maximum), while the lowest was found at Bank Mayapada Internasional Tbk and the National Pension Savings Bank Tbk (0.40) (minimum).

The independent audit committee variable (X2) that occurs in banking companies has an average of 0.6100 with a standard deviation of 0.12035. The highest number of independent audit committee is Bank Artha Graha Internasional Tbk (0.80), and the lowest was for Bank Pembangunan Daerah Jawa Timur Tbk, and Bank Mandiri (Persero) Tbk (0.33).

The managerial ownership structure variable (X3) that occurs in banking companies has an average of 0.573 with a standard deviation of 0.146505. The highest managerial ownership was found at Bank Bukopin Tbk (0.63), and the lowest at Bank OCBC NISP Tbk (0.01).

The dividend policy variable $\left(\mathrm{X}_{4}\right)$ that occurs in banking companies has an average of 0.3749 with a standard deviation of 0.19290. The highest value of dividend policy is at Bank Nusantara Parahyangan Tbk, which is 0.91, and the lowest is at Bank Central Asia Tbk, which is 0.08.

Table 2. Multiple Linear Regression.

\begin{tabular}{l|c}
\hline Model & B \\
\hline Earnings Management & 2.528 \\
\hline Independent Board of Commissioners & -1.162 \\
\hline Independent Audit Committee & -2.113 \\
\hline Managerial Ownership & 3.323 \\
\hline Dividend Policy & -3.808 \\
\hline
\end{tabular}

The method of data analysis was carried out using multiple linear regression to see the relationship between the independent variables and the dependent variable. The multiple linear regression results in Table 2 above were obtained from the following equation:

$$
\mathrm{Y}=2.528-1.162 \mathrm{X}_{1}-2.113 \mathrm{X} 2+3.323 \mathrm{X} 3-3.808 \mathrm{X}_{4}+\mathrm{e}
$$

The constant $(\alpha)$ is 2.528, which means that if all independent variables are constant or equal to zero (0), then the earnings management is 2.528 units. In other words, the magnitude of the earnings management variable (Y), which is not influenced by the independent board of commissioners, independent audit committee, managerial ownership, and dividend policy variables, is 2.528 units. The independent board of commissioners variable (X1) has a regression coefficient value of -1.162 . The negative result here means that if the independent board of commissioners increases by one unit, then the earnings management variable will decrease by 1.162 units, with the condition that other variables are considered constant. The independent audit committee variable (X2) has a regression coefficient of -2.113 . This negative result means that if the independent audit committee variable increases by one unit, then the earnings management variable will decrease by 2.113 , provided that other variables are considered constant. The managerial ownership variable (X3) has a regression coefficient value of 3.323. This positive value indicate that if the managerial ownership variable increases by one unit, the earnings management variable will increase by 3.323 units, with other variables being held constant. The dividend policy variable (X4) has 
a regression coefficient of -3.808 . This negative result means that if the dividend policy variable increases by one unit, the earnings management variable will decrease by 3.808, provided that other variables are considered constant.

Table 3. Normality Test (One-sample Kolmogorov-Smirnov test).

\begin{tabular}{|c|c|c|}
\hline & & Standardized Residual \\
\hline $\mathbf{N}$ & & 54 \\
\hline Asymp. Sig. (2-tailed) & 0.001 & \\
\hline
\end{tabular}

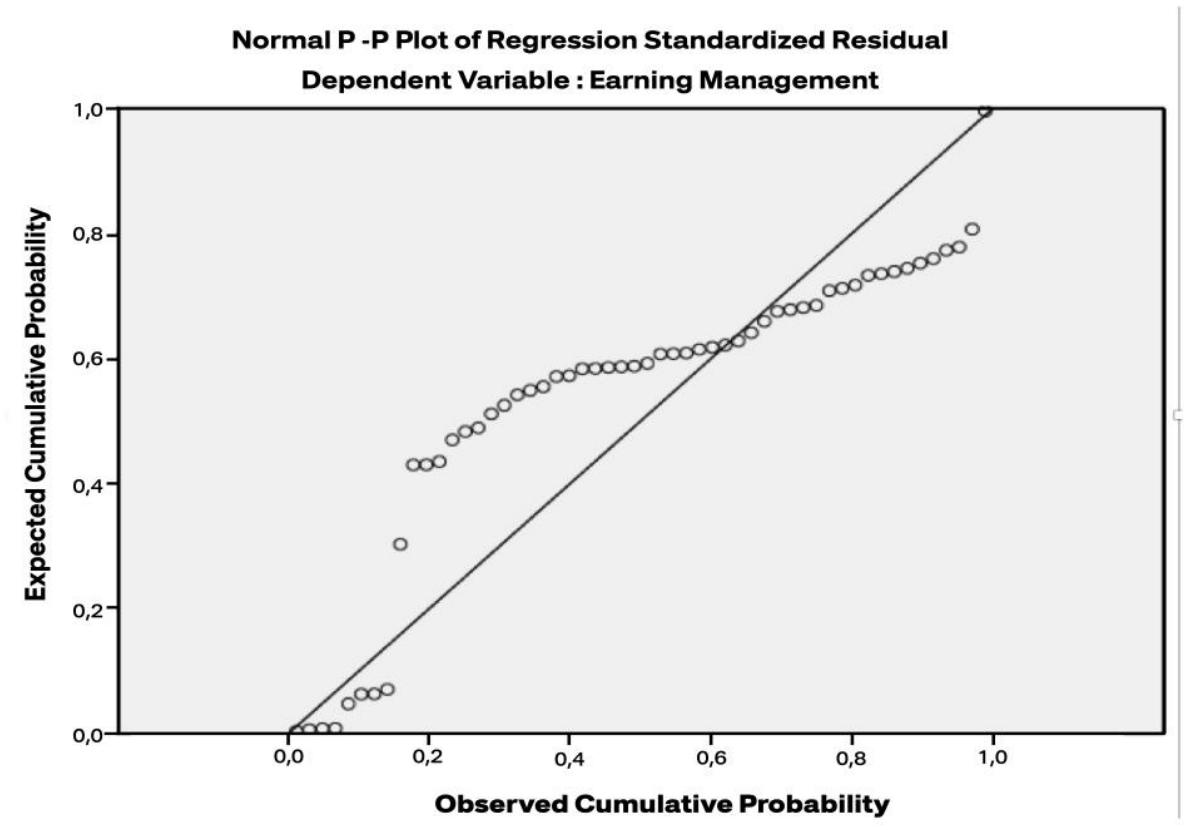

Figure 1. Normal P-P Plot of Regression. Standardized Residual. Dependent Variable: Earning Management.

The normality test aims to test whether the error term has a normal distribution or not. In this case, the normality test used is the non-parametric statistical One-Sample Kolmogorov-Smirnov test. This test is used to provide more detailed figures to confirm whether there is normality or not in the data. Normality occurs when the Kolmogorov-Smirnov test result is more than 0.05. From the results of the One-Sample Kolmogorov-Smirnov test shown in Table 3, it can be stated that the error is not normally distributed because the significant value is less than 0.05. In addition, the P-P plot graph in Figure 1 also shows that the distribution of the data tends to be far from the diagonal line of normality. However, some are still approaching the diagonal line, so it can be said that the distribution of the data in this study is normal.

Table 4. Multicollinearity test.

\begin{tabular}{l|c|c|c}
\hline \multirow{2}{*}{ Model } & \multicolumn{2}{|c|}{ Collinearity Statistics } & Result \\
\cline { 2 - 4 } & Tolerance & VIF & \\
\hline Independent Board of Commissioners & 0.957 & 1.044 & Free from multicollinearity \\
\hline Independent Audit Committee & 0.798 & 1.253 & Free from multicollinearity \\
\hline Managerial Ownership & 0.917 & 1.091 & Free from multicollinearity \\
\hline Dividend Policy & 0.786 & 1.273 & Free from multicollinearity \\
\hline
\end{tabular}

The multicollinearity test aims to test whether the regression model found a correlation between the independent variables. In a good regression model, there should be no correlation between the independent variables. The presence or absence of multicollinearity in the regression model can be determined from the tolerance value and variance inflation factor (VIF). The cut-off value commonly used to indicate the presence of 
multicollinearity is the tolerance value of 0.10 , or the same as the VIF value of 10. Table 4 contains the results of the multicollinearity test, where the tolerance values for all independent variables is less than 10, and the VIF values for all independent variables is also less than 10. Based on this data, it can be stated that all variables in this study did not experience symptoms of multicollinearity.

\section{Scatterplot}

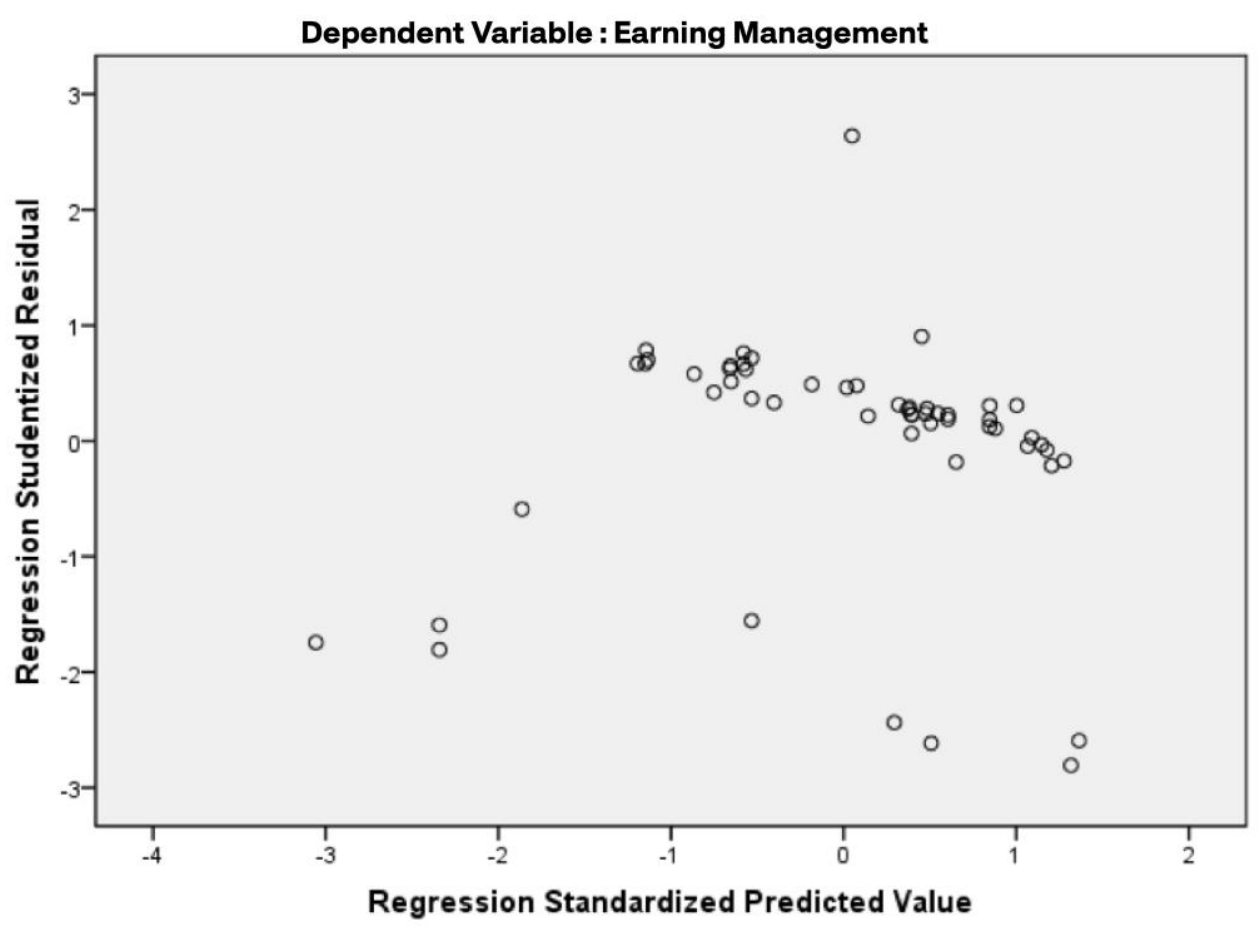

Figure 2. Scatterplot.

The heteroscedasticity test aims to test whether there is an inequality of variance from the residuals of one observation to another in the regression model by using scatterplots graphs. A good regression model is one where heteroscedasticity does not occur. If there are points that form a certain pattern on the scatterplot graph, it indicates that heteroscedasticity has occurred. If there is no clear pattern, and the points are spread above and below the number $\mathrm{O}$ on the $\mathrm{Y}$ axis, there is no heteroscedasticity. The points in the scatterplot graph in Figure 2 are randomly distributed, although there are a few parts that converge. They do not form a certain pattern, so it can be said that the four variables in this study do not have heteroscedasticity problems.

Table 5. Autocorrelation Test.

\begin{tabular}{c|c}
\hline Model & Durbin-Watson \\
\hline 1 & 2.021 \\
\hline
\end{tabular}

The autocorrelation test aims to test whether there is a correlation between the error term in period $t$ and the error term in period t-1 (previous period) in the regression model. To detect autocorrelation symptoms, the Durbin-Watson test can be used, where the test results are determined based on the Durbin-Watson value. From the information in Table 5 above, it can be seen that the Durbin-Watson value is 2.021 with a dL value of $=1.414$ and a $\mathrm{dU}$ value of $=1.724$. So, $4-\mathrm{dL}=4-1.414=2.586$, and $4-\mathrm{dU}=4-1.724=2.276$. The value of 2.021 is between $\mathrm{dU}$ and $4-\mathrm{dU}$, so it can be said that the Durbin-Watson test in this study was free from autocorrelation problems. 
Table 6. Determinant Coefficient Test $\left(\mathrm{R}^{2}\right)$.

\begin{tabular}{c|c}
\hline Model & Adjusted R-Squared \\
\hline 1 & 0.117 \\
\hline
\end{tabular}

The coefficient of determination is a measuring tool used to measure the percentage of the influence of the independent variable (predictor) on the variation of the dependent variable. The measurement of the percentage of truth from the regression test can be seen through the coefficient of determination of multiple $\mathrm{R}^{2}$. The value of the coefficient of determination lies between $\mathrm{O}$ and $1\left(\mathrm{O}<\mathrm{R}^{2}<1\right)$, where the higher the $\mathrm{R}^{2}$ of a regression or the closer to 1 , the better the regression results. This means that the independent variables provide almost all the information needed to predict the variation of the dependent variable. Based on the information in Table 6, which shows the results of the determinant coefficient test, we can conclude that the independent board of commissioners (X1), independent audit committee (X2), managerial ownership (X3) and dividend policy (X4) have a contribution relationship to earnings management $(\mathrm{Y})$ in banking companies listed on the Indonesia Stock Exchange (IDX) from 2015 to 2017 of $11.7 \%$.

Table 7. F-Test (F).

\begin{tabular}{c|c|c}
\hline Model & F & Sig. \\
\hline Regression & 2.709 & 0.037 \\
\hline
\end{tabular}

Testing at this stage is to determine whether the regression model is appropriate. If the calculated $\mathrm{F}$ is greater than the $\mathrm{F}$ table, or the probability is less than the significance level (Sig. $<0.05$ ), then the research model is considered to be appropriate and can be used. The results of the F-test in Table 7 state that the F-count is 2.709 with a significance value of 0.037 . A significance value of 0.037 , which is $<0.05$, indicates that this model can be used for testing.

Table 8. Individual parameter statistics t-test.

\begin{tabular}{l|c|c|c|c}
\hline Variable & B & T & Sig. & Result \\
\hline Independent Board of Commissioners & -1.162 & -0.364 & 0.717 & Not accepted \\
\hline Independent Audit Committee & -2.113 & -0.838 & 0.406 & Not accepted \\
\hline Managerial Ownership & 3.323 & 0.172 & 0.864 & Not accepted \\
\hline Dividend Policy & -3.808 & -2.402 & 0.020 & Accepted \\
\hline
\end{tabular}

The statistical t-test basically shows how far the influence of one variable goes in explaining the dependent variable. The t-test can be done by looking at the significance probability value of $\mathrm{T}$ on each of the variables contained in the output of the regression results using SPSS software. If the significance probability value of $\mathrm{T}$ is less than 0.05, it can be said that there is a strong influence between the independent variable and the dependent variable. Based on the results of the individual parameter test, as seen in Table 8 , the significance value of the independent board of commissioners is 0.717 , the independent audit committee is 0.406 , the managerial ownership structure is 0.864 , and the dividend policy has a significance value of 0.020 . The hypothesis will be proven if the direction is appropriate, and the significance level is below 0.05.

\section{DISCUSSION}

Based on the results of the data analysis, it can be seen that the independent board of commissioners has no effect on earnings management in banking companies. When viewed from the results of partial hypothesis testing, it shows that the independent board of commissioners has a significance level of 0.717 , which is greater than 0.05 , and this means that the independent board of commissioners has no partial effect on earnings management in banking companies. Independent commissioners in Indonesia also use a two-tier system, which consists of a board 
of commissioners and a board of directors. The board of commissioners is in charge and responsible for monitoring the quality of the information contained in the financial statements. From the results of the study, it was found that the independent board of commissioners had no effect on earnings management. This may be because the supervisory or monitoring function in the company has not been optimally and comprehensively limited to earnings management restrictions. In practice, although the composition of the board of commissioners in the company is relatively large, they cannot actually carry out their duties and supervision because they are limited by regulations/policies of the majority shareholder. As a result, the existence of an independent commissioner is only to comply with the existing regulations and is not intended for the enforcement of good corporate governance (Gideon, 2005; Siregar \& Utama, 2005; Ujiyantho \& Scouts, 2007). These findings support the research conducted by Peasnell, Pope, \& Young (2000); Persons (2005); Nuryaman, Rusmin, \& Ginting (2010); Rahmawati (2013); Hermiyetti \& Manik (2013); Khosheghbal et al. (2017) and Handoyo \& Agustianingrum (2017). According to Nuryaman et al. (2010), some of the reasons why the composition of the board of commissioners had no effect on earnings management are: (1) empirical evidence shows that the average composition of the board of commissioners is relatively low, so the independent commissioners have no power to influence board decisions, and (2) it is possible that the board of commissioners is not competent in accounting and finance. From the results of the independent board of commissioners variable, it can be seen that the independent audit committee had no partial effect on earnings management in banking companies listed on the Indonesia Stock Exchange from 2015 to 2017 . The results of partial hypothesis testing indicate that the independent audit committee has a significance level of 0.406 , which is greater than 0.05 , and this means that the independent audit committee has no partial effect on earnings management. The independent audit committee is also required to have experience in order to be fairer and objective in dealing with problems and to provide views on issues related to the company's financial policies. The results of this study cannot support the theory that the greater audit committee size will reduce earnings management practices due to increased corporate control. This is possible because the audit committee can interact with company management to improve the effectiveness of management performance through earnings management (Peasnell et al., 2000). In addition, according Peasnell et al. (2000), the interaction between the audit committee and management can be done to maximize the company's revenue. These results are in line with the results of research conducted by Murhadi (2010); Hermiyetti \& Manik (2013); Suriyani et al. (2015); Yendrawati (2015); Khosheghbal et al. (2017) and Handoyo \& Agustianingrum (2017).

The third variable in this study - corporate governance - refers to management ownership. From the results of data analysis, it can be concluded that the managerial ownership structure has no partial effect on earnings management in banking companies listed on the IDX between 2015 and 2017. The results of partial hypothesis testing indicate that the managerial ownership structure has a significance level of 0.864 , which is greater than 0.05 , and this means that the managerial ownership structure has no partial effect on earnings management. This may be because not all banking companies have a share ownership by management policy. If such a policy exists, the possibility of share ownership by the management is no more than $5 \%$ of the total shares. In addition, managerial ownership was found to be an effective monitoring mechanism, particularly in small firms (Kazemiana \& Zuraidah, 2015). The results of this study are in line with the results of research conducted by Rahmawati (2013); Hermiyetti \& Manik (2013) and Khosheghbal et al. (2017) in Iran. Of the three variables of corporate governance, it turns out that none of them can prove that it can prevent the occurrence of earnings management. This shows that the level of risk of earnings management behavior in Indonesia in the banking sector is still very large because the corporate governance mechanism does not work well. This is in line with research done by Leuz, Nanda, \& Wysocki (2003); Lang, Raedy, \& Wilson (2006) and Gopalan \& Jayaraman (2012), who stated that earnings management practices in developing countries such as Indonesia are more common than in developed countries. In contrast to the three corporate governance variables, the dividend policy variable was shown to have a significant partial negative effect on the earnings management in banking companies. The results of the partial hypothesis testing indicate that 
dividend policy has a significance level of 0.020 , which is less than 0.05 , and this means that dividend policy has a significant negative effect on earnings management in banking companies. Companies that have very high profits tend not to use earnings management because this is considered to increase the risk of being read by investors. Therefore, the company chooses to reduce profits by distributing dividends. So, it can be said that a high dividend payout ratio is an indication that the company does not use earnings management because profits will automatically decline. If management wants a low dividend distribution, earnings management practice will be used by the company. Likewise, if the company wants a high dividend distribution, the company tends not to practice earnings management. In other words, only companies that have small profits tend to carry out earnings management (Aflatooni \& Nikbakht, 2010). This is done by companies that want to maintain their ability to raise funds in the capital market, especially in less financially developed markets such as Indonesia (He et al., 2017), or it can be said to build a reputation that will facilitate future access to capital markets (La Porta, Silanes, Shleifer, \& Vishny, 2000). The results of this study support the results of research conducted by Aflatooni \& Nikbakht (2010); Putri (2012) and He et al. (2017).

\section{CONCLUSION}

The existence of good corporate governance is expected in the management of a company and in the presentation of financial statements. It is presumed that these do not contain biased information for users. However, this study proves the opposite, that the existence of good corporate governance does not guarantee that management will not display functional behavior, such as income smoothing, in banking companies in Indonesia. This study found that dividend policy could significantly influence a decline in this unethical behavior.

\section{IMPLICATIONS}

The existence of a good corporate governance mechanism is not a guarantee that the organization does not carry out earnings management, meaning that there is no inversely proportional relationship between good corporate governance and earnings management. However, this study shows that only dividend policy can suppress earnings management practices, especially in the case of banking sector companies. This indicates that it is not a good system that can guarantee the reduction of earnings management practices but depends on the good intentions of company managers, so it is important for investors to know who the management and board of commissioners of the company are and where they invest their funds. Additionally, related agencies need to pay more attention to the annual financial statements reported.

\section{SUGGESTIONS}

Earnings management is carried out by management not only to attract potential investors to invest in the company; it is also used in order to avoid large taxes, especially in countries that apply high corporate tax rates. Therefore, further research could include tax avoidance as a control variable.

Funding: This study received no specific financial support.

Competing Interests: The authors declare that they have no competing interests.

Acknowledgement: Both authors contributed equally to the conception and design of the study.

\section{REFFERECES}

Aflatooni, A., \& Nikbakht, Z. (2010). Income smoothing, real earnings management and long-run stock returns. Business Intelligence Journal, 3(1), 55-74.

Alves, S. (2012). Ownership structure and earnings management: Evidence from Portugal. Australasian Accounting, Business and Finance Journal, 6(1), 57-74. 
Christie, A. A., \& Zimmerman, J. L. (1994). Efficient and opportunistic, choices of accounting procedures: Corporate control contest. Accounting Revierw, 3(2), 53-66.

Chtourou, S. M., Bédard, J., \& Courteu, L. (2001). Corporate governance and earnings management [Working Paper]. Social Science Research Network. Retrieved https://www.researchgate.net/publication/228253511_Corporate_Governance_and_Earnings_Management

Dewi, S., Eva, R., \& Khoiruddin, M. (2016). The effect of good corporate governance on earnings management in companies that are included in the JII (Jakarta Islamic Index) 2012-20 13. Management Analysis Journal, 5(3), 156-166.

Eisenhardt, K. (1989). Agency theory: An assesment and review. Academy of Management Revierw, 14(1), 57-74.

Gideon, S. B. B. (2005). Earnings quality: Study of the effect of corporate governance mechanisms and the impact of earnings management using path analysis. Paper presented at the VIII National Accounting Symposium, Solo. pp. 172-194. September 15-16.

Gopalan., R., \& Jayaraman, S. (2012). Private control benefits and earnings management: Evidence from insider controlled firms. Journal of Accounting Research, 5o(1), 117-157. Available at: https://doi.org/10.1111/j.1475-679x.2011.00431.x.

Gordon, M. J. (1960). Security and a financial theory of investment. The Quarterly Journal of Economics, 74(3), 472-492.

Haider, J. (2012). Earning management and dividend policy: Empirical evidence from Pakistani listed companies. European Journal of Business and Management, 4(1), 83-90.

Handoyo, S., \& Agustianingrum, W. B. (2017). GCG role and audit quality in reducing earnings management action in Indonesian manufacturing firms. Journal of Finance and Banking, 21(3), 436-445. Available at: https://doi.org/10.26905/jkdp.v2 1i3.673.

Handoyo, S., \& Fathurrizki, S. (2018). Management dysfunctional behavior toward financial statements: Income smoothing practice in Indonesia's mining industry sector. Journal of Finance and Banking, 22(3), 429-442. Available at: https://doi.org/10.26905/jkdp.v22i3.2047.

Harrast, S. A., \& Mason-Olsen, L. (2007). Can audit committees prevent management fraud?: Certified public accountant. The CPA Journal, 77(1), 24-27.

He, W., Ng, L., Zaiats, N., \& Zhang, B. (2017). Dividend policy and earnings management across countries. Journal of Corporate Finance, 42, 267-286. Available at: https://doi.org/10.1016/j.jcorpfin.2016.11.014.

Hermiyetti, \& Manik. (2013). The influence of good corporate governance mechanism on earnings management: Empirical study in Indonesian stock Exchange listed Company for Periods of 2006-2010. Indonesian Capital Market Review, 5(1), 52-63. Available at: https://doi.org/10.21002/icmr.v5i1.1583.

Hodnett, K., \& Hsieh, H. (2012). Capital market theories: Market efficiency versus investor prospects. International Business $\Xi^{\circ}$ Economics Research Journal, 11(8), 849-862. Available at: https://doi.org/10.19030/iber.v 11 i8.7163.

Iqbal, A., \& Strong, N. (2010). The effect of corporate governance on earnings management around UK rights issues. International Journal of Managerial Finance, 6(3), 168-189. Available at: https://doi.org/10.1 108/17439131011056215.

Jensen, M. C., \& Meckling, W. H. (1976). Theory of the firm: Managerial behavior, agency costs and ownership structure. Journal of Financial Economics, 3(4), 305-360.

Kazemiana, S., \& Zuraidah, M. S. (2015). Earnings management and ownership structure. Procedia Economics and Finance, 31,618 -624 .

Khosheghbal, M., Ali, A., \& Ali, H. (2017). Role of audit committees and board of directors in reducing earning management of companies listed in Tehran Stock Exchange. International Journal of Economics and Financial Issues, 7(6), 147-153.

Komite Nasional Kebijakan Governance (KKNG). (2006). Pedoman Umum good corporate governance Indonesia: Coordinator of Ministry of Economics.

La Porta, F., Silanes, F., Shleifer, A., \& Vishny, R. (2000). Agency problems and dividend policies around the world. The Journal of Finance, 55(1), 1-33. Available at: https://doi.org/10.2139/ssrn.52871.

Lang, M., Raedy, J. S., \& Wilson, W. (2006). Earnings management and cross listing: Are reconciled earnings comparable to US earnings. Journal of Accounting and Economics 42(1-2), 255-283. Available at: https://doi.org/10.1016/j.jacceco.2006.04.005. 
Law, P. (2011). Corporate governance and no fraud occurrence in organizations Hong Kong evidence. Managerial Auditing Journal, 26(6), 501-518. Available at: https://doi.org/10.1108/02686901111142558.

Leuz, C., Nanda, D., \& Wysocki, P. D. (2003). Earnings management and investor protection: An international comparison. Journal of Financial Economics, 69(3), 505-527. Available at: https://doi.org/10.1016/s0304-405x(03)00121-1.

Lin, T. Y., \& Min-Yen, C. (2014). Impact of an independent director system on a board of directors and the system's relation to corporate performance. Case study of listed companies in Taiwan. Investment Management and Financial Innovations, $11(1), 56-69$.

Lintner, J. (1962). Dividends, earnings, leverage, stock prices and the supply of capital to corporations. The review of Economics and Statistics, 44(3), 243-269. Available at: https://doi.org/10.2307/1926397.

Litzenberger, R. H., \& Ramaswamy, K. (1982). The effects of dividends on common stock prices tax effects or information effects? The Journal of Finance, 37(2), 429-443. Available at: https://doi.org/10.2307/2327350.

Mahadewi, A. A. I. S., \& Krisnadewi, K. A. (2017). Effect of managerial, institutional ownership and the proportion of independent commissioners on earnings management. Udayana University Accounting E-Journal, 18(1), 443-470.

Mansor, N., Che-Ahmad, A., Ahmad-Zaluki, N. A., \& Osman, A. H. (2013). Corporate governance and earnings management: A study on the malaysian family and non-family owned PLCs. Procedia Economics and Finance, 7, 22 1-229. Available at: https://doi.org/10.1016/s2212-5671(13)00238-4.

Miller, M. H., \& Modigliani, F. (1961). Dividend policy, growth, and the valuation of shares. The Journal of Business, 34(4), 411433. Available at: https://doi.org/10.1086/294442.

Murhadi, W. R. (2010). Good corporate governance and earning management practices: An Indonesian Cases. Retrieved from: https://ssrn.com/abstract $=1680186$ or http://dx.doi.org/10.2139/ssrn.1680186.

Nastiti, A. S., Gumanti, T. A., Utami, S. R., \& Manik, E. (2015). Corporate governance and earnings management on initial public offering. Mediterranean Journal $f$ Social Science, 6(5), 223-229. Available at: https://doi.org/10.5901/mjss.2015.v6n5s5p223.

Nuryaman, R., Rusmin, R., \& Ginting, J. (2010). Effect of ownership structure and audit quality on earnings management. XIVO's Journal of Accounting, 14(2), 152-164.

O'Callaghan, S., Ashton, J., \& Hodgkinson, L. (2018). Earnings management and managerial ownership in private firms. Journal of Applied Accounting Research, 19(4), 648-668. Available at: https://doi.org/10.1108/jaar-11-2017-0124.

Peasnell, K. V., Pope, P. F., \& Young, S. (2000). Detecting earnings management using cross-sectional abnormal accruals models. Accounting छ Business Research, 30(4), 313-326.

Persons, O. S. (2005). The relation between the new corporate governance rules and the likelihood of financial statement fraud. Review of Accounting and Finance, 4(2), 125-149. Available at: https://doi.org/10.1 108/eb043426.

Putri, I. G. A. M. A. D. (2012). The effect of dividend policy and good corporate governance on earnings management. Economic Studies Bulletin, 17(2), 157-171.

Rahmawati, H. (2013). The effect of good corporate governance (GCG) on earnings management in banking companies. Accounting Analysis Journal, 2(1), 9-18.

Raja, D. R., Anugerah, R., Desmiyawati, \& Kamaliah. (2014). Earnings management activities: analysis of audit committee role, institutional ownership, public share percentage and leverage. Mataram: National Accounting Symposium.

Santana, D. K. W., \& Made, G. W. (2016). The effect of tax planning, managerial ownership and firm size on earnings management practices. Udayana University Accounting E-Journal, 14(3), 1555-1583.

Scott, W. R. (2009). Financial accounting theory (5th ed.). Canada: Prentice Hall.

Sinan, A. S., Hijazi, Q. F., \& Al-Rahahleh, A. S. (2016). Corporate governance quality and earnings management: Evidence from Jordan. Australasian Accounting, Business and Finance Journal, 10(2), 54-75. Available at: https://doi.org/10.14453/aabfj.v10i2.4.

Siregar, S. V. N., \& Utama, S. (2005). The effect of ownership structure, firm size, and corporate governance practices on earnings management (Earning Management). Solo National Accounting Symposium, 7. 
Sufitrayati, S. (2015). Effect of concentration of institutional ownership, firm size and composition of the board of commissioners on earnings management. Journal of Management Economics and Accounting, 1(1), 36-44.

Sulistiyawati, S. (2013). The effect of firm value, dividend policy, and auditor reputation on income smoothing. Accounting Analysis Journal, 2(2), 148-153.

Sun, J., Lan, G., \& Liu, G. (2014). Independent audit committee characteristics and real earnings management. Managerial Auditing Journal, 29(2), 153-172.

Suriyani, P. P., Yuniarta, G. A., \& Atmadja, A. T. (2015). Factors that affect earnings management (empirical studies on manufacturing companies listed on the IDX for the 2008-2013 period). Ganesha University of Education E-Journal, 3(1).

Syarifuddin, A. (2013). Analysis of the influence of managerial ownership structure and good corporate governance mechanisms on earnings management (Empirical Study on Manufacturing Companies Listed on the Indonesia Stock Exchange in 2008-2010). Akmen Scientific Journal, 10(4), 570-590.

Teshima, N., \& Okinobu, S. (2008). Managerial ownership and earnings management: Theory and empirical evidence from Japan. Journal of International Financial Management and Accounting, 19(2), 108-132. Available at: https://doi.org/10.1111/j.1467-646x.2008.01018.x.

Ujiyantho, A. M., \& Scouts, B. A. (2007). Corporate governance mechanisms, earnings management and financial performance. Paper presented at the X National Accounting Symposium, Makassar.

Xie, B., Davidson III, W. N., \& DaDalt, P. J. (2003). Earning management and corporate governance: The commitee. Journal of Corporate Finance, 9(2), 295-316.

Yendrawati, R. (2015). Effect of independent board of commissioners, audit committee, managerial ownership, and institutional ownership on earnings management. Journal of Entrepreneur and Entrepreneurship, 4(1), 33-40. 